\title{
PENGARUH OLAHRAGA TERPROGRAM TERHADAP \\ TEKANAN DARAH DAN DAYA TAHAN KARDIORESPIRASI \\ PADA ATLET PELATDA SLEMAN CABANG TENIS LAPANGAN
}

\section{Oleh: Abdul Alim \\ Dosen Jurusan Pendidikan Kepelatihan Olahraga FIK-UNY}

\begin{abstract}
Abstrak
Perubahan fungsi kardiovaskuler akibat latihan olahraga secara teratur akan mempengaruhi nilai Tekanan Darah. Penelitian ini bertujuan untuk mengetahui pengaruh latihan olahraga tenis secara terprogram selama 12 minggu terhadap tekanan darah dan daya tahan kardio respirasi pada atlet pelatda sleman cabang olahraga tenis lapangan.

Rancangan penelitian ini adalah quasi experimental dengan one group pretestposttest design. Sampel penelitian adalah atlet pelatda sleman cabang tenis lapangan berjumlah 10 orang, yang memenuhi kriteria inklusi dan eksklusi. Kelompok perlakuan menerima latihan tenis terprogram, yaitu latihan 3 kali seminggu selama 120 menit setiap latihan. Sphygmomanometer digunakan untuk mengukur tekanan darah pada pembuluh arteri perifer.

Hasil penelitian menunjukkan (1) Ada peningkatan daya tahan kardiorespirasi yang signifikan $(p<0,05)$ pada atlet yang mengikuti latihan tenis secara teratur selama 12 minggu. (2) Ada penurunan tekanan darah yang signifikan $(\mathrm{p}<0,05)$ pada atlet yang mengikuti latihan tenis secara teratur selama 12 minggu.
\end{abstract}

Kata Kunci : tekanan darah, latihan olahraga teratur

Berbagai aktivitas olahraga yang dilakukan manusia bertujuan untuk meningkatkan kualitas fisiknya, terutama apabila dilakukan secara benar dan teratur. Latihan olahraga aerobik, terutama bermanfaat untuk meningkatkan dan mempertahankan kesehatan dan daya tahan jantung, paru, peredaran darah, otot-otot, dan sendi-sendi. Menurut Bompa (1994:23) suatu latihan olahraga yang dilakukan secara teratur akan memberikan pengaruh yang besar terhadap tubuh. Latihan fisik dengan pembebanan tertentu akan mengubah faal tubuh, yang selanjutnya akan mengubah tingkat kesegaran jasmani. Perubahan secara cepat disebut respon, sedangkan perubahan lambat akibat olahraga atau latihan teratur disebut adaptasi. Tenis merupakan salah satu jenis olahraga yang berkembang dan banyak diminati di masyarakat.

Semakin banyak jenis olahraga yang ditawarkan, semakin mudah bagi masyarakat untuk memilih dan melakukan olahraga yang disenangi, meskipun amat disayangkan karena hanya $26,2 \%$ dari masyarakat Indonesia yang berusia $10-30$ tahun yang melakukan olahraga. 


\section{MEDIKORA Vol. VIII, No 2 April 2012}

Dengan alasan inilah penulis merasakan perlunya dilakukan pendekatan secara ilmiah untuk membuktikan pengaruh olahraga terhadap kesehatan, terutama faal tubuh.

Salah satu pendekatan secara ilmiah tersebut dapat dilakukan dengan melihat pengaruh olahraga terhadap daya tahan kardiorespirasi dan tekanan darah. Hasil dari penelitian ini diharapkan dapat menambah bahan acuan mengenai pengaruh olahraga terhadap penurunan daya tahan kardiorespirasi dan tekanan darah serta memberi informasi kepada masyarakat mengenai pentingnya olahraga terhadap kesehatan, terutama nilai positif olahraga terhadap tekanan darah. Disamping itu diharapkan juga tumbuhnya kesadaran masyarakat mengenai pentingnya berolahraga, sebagai upaya preventif dari kejadian hipertensi.

Cerika (2008:48) mendapatkan adanya hubungan antara olahraga dengan penurunan resiko hipertensi. Penelitian menunjukkan bahwa penurunan tekanan darah sebesar $5 \mathrm{mmHg}$ akan menyebabkan penurunan kejadian stroke sebanyak 40\% dan penurunan kejadian infark miokard sebanyak 15\% pada subjek penderita hipertensi yang telah mengalami penurunan tekanan darah. Berdasar uraian di atas, penulis merasa perlu untuk melakukan penelitian mengenai perbedaan Tekanan Darah antara sebelum dan sesudah individu melakukan latihan secara benar dan teratur. Hasil dari penelitian ini diharapkan dapat menambah bahan acuan mengenai pengaruh olahraga terhadap penurunan tekanan darah dan daya tahan kardiorespirasi, serta memberi informasi kepada masyarakat mengenai pentingnya olahraga terhadap kesehatan, terutama nilai positif olahraga terhadap tekanan darah.

\section{KARAKTERISTIK PERMAINAN TENIS}

Prinsip dasar dalam permainan tenis adalah memukul bola melewati net dan masuk dalam lapangan permainan lawan. Pada saat memukul bola diusahakan agar menyulitkan pengembalian bola dari lawan. Penggunaan taktik dalam bermain tenis secara garis besar bersifat menyerang dan bertahan atau kombinasi dari keduanya. Prinsip dasar bertahan yang baik adalah melakukan penyerangan. Untuk itu taktik dasar bermain tenis adalah menghindari terjadinya kesalahan yang dilakukan sendiri, seperti memukul bola menyangkut di net, atau memukul bola keluar dari daerah lapangan permainan. Dengan demikian penerapan taktik dasar yang sederhana dalam tenis adalah berusaha memukul bola untuk selalu masuk ke dalam lapangan permainan lawan. Agar dapat menerapkan taktik tersebut diperlukan kemampuan dan penguasaan keterampilan teknik, kondisi fisik, dan psikis.

\section{DAYA TAHAN KARDIORESPIRASI}

Daya tahan kardiorespirasi adalah kesanggupan sistem jantung, paru, dan pembuluh darah untuk berfungsi secara optimal pada keadaan istirahat dan kerja dalam mengambil 


\section{MEDIKORA Vol. VIII, No 2 April 2012}

oksigen dan menyalurkannya ke jaringan yang aktif sehingga dapat digunakan pada proses metabolisme tubuh (Giam, C.K., 1993). Daya tahan kardiorespirasi merupakan komponen terpenting dari kesegaran jasmani. Daya tahan kardiorespiasi yang tinggi menunjukkan kemampuan untuk bekerja yang tinggi, yang berarti kemampuan untuk mengeluarkan sejumlah energi yang cukup besar dalam periode waktu yang lama. Daya tahan dalam dunia olahraga dikenal sebagai kemampuan peralatan tubuh olahragawan untuk melawan kelelahan selama aktivitas atau kerja berlangsung. Olahragawan yang memiliki ketahanan baik, mampu bekerja lebih lama dan tidak akan cepat merasa lelah. Daya tahan kardiorespirasi dipengaruhi beberapa faktor yakni genetik, umur dan jenis kelamin, aktivitas fisik, komposisi lemak tubuh dan kebiasaan merokok.

Daya tahan kardiovaskuler dipengaruhi oleh faktor genetik yakni sifat-sifat spesifik yang ada dalam tubuh seseorang sejak lahir. Pengaruh genetik pada kekuatan otot dan daya tahan otot pada umumnya berhubungan dengan komposisi serabut otot yang terdiri dari serat merah dan serat putih. Seseorang yang memiliki serat merah lebih banyak, lebih tepat untuk melakukan kegitan bersifat aerobic, sedangkan yang lebih banyak memiliki serat otot rangka putih, lebih mampu melakukan kegiatan yang bersifat anaerobic. Demikian pula pengaruh keturunan terhadap komposisi tubuh, sering dihubungkan dengan tipe tubuh. Seseorang yang mempunyai tipe endomorf (bentuk tubuh bulat dan pendek) cenderung memiliki jaringan lemak yang lebih banyak bila dibandingkan dengan tipe otot ektomorf (bentuk tubuh kurus dan tinggi) (Giam, C.K., 1993).

Umur mempengaruhi hampir semua komponen kesegaran jsmani. Daya tahan kardiovaskuler menunjukkan suatu tendensi meningkat pada masa anak-anak sampai sekitar dua puluh tahun dan mencapai maksimal di usia 20 sampai 30 tahun. Daya tahan tersebut akan makin menurun sejalan dengan bertambahnya usia, dengan penurunan $8-10 \%$ perdekade untuk individu yang tidak aktif, sedangkan untuk individu yang aktif penurunan tersebut 45\% perdekade (Giam, C.K., 1993). Peningkatan kekuatan otot pria dan wanita sama sampai usia 12 tahun, selanjutnya setelah usia pubertas pria lebih banyak peningkatan kekuatan otot, maksimal dicapai pada usia 25 tahun yang secara berangsur-angsur menurun dan pada usia 65 tahun kekuatan otot hanya tinggal $65-70 \%$ dari kekuatan otot sewaktu berusia 20 sampai 25 tahun. Pengaruh umur terhadap kelenturan dan komposisi tubuh pada umumnya terjadi karena proses menua yang disebabkan oleh menurunnya elastisitas otot karena berkurangnya aktivitas dan timbulnya obes pada usia tua (Giam, C.K., 1993).

Kesegaran jasmani antara pria dan wanita berbeda karena adanya perbedaan ukuran tubuh yang terjadi setelah masa pubertas. Daya tahan kardiovaskuler pada masa pubertas 


\section{MEDIKORA Vol. VIII, No 2 April 2012}

terdapat perbedaan, karena wanita memiliki jaringan lemak yang lebih banyak dibandingkan pria. Hal yang sama juga terjadi pada kekuatan otot, karena perbedaan kekuatan otot antara pria dan wanita disebabkan oleh perbedaan ukuran otot baik besar maupun proposinya dalam tubuh.

Kegiatan yang mempengaruhi semua komponen kesegaran jasmani, seperti latihan yang bersifat aerobik yang di lakukan secara teratur dapat meningkatkan daya tahan kardiovaskuler dan dapat mengurangi lemak tubuh. Dengan melakukan latihan olahraga atau kegiatan fisik yang baik dan benar berarti seluruh organ dipicu untuk menjalankan fungsinya sehingga mampu beradaptasi terhadap setiap beban yang diberikan. Latihan fisik akan menyebabkan otot menjadi kuat. Perbaikan fungsi otot, terutama otot pernapasan menyebabkan pernapasan lebih efisien pada saat istirahat.Ventilasi paru pada orang yang terlatih dan tidak terlatih relatif sama besar, tetapi orang yang berlatih bernapas lebih lambat dan lebih dalam. Hal ini menyebabkan oksigen yang diperlukan untuk kerja otot pada proses ventilasi berkurang, sehingga dengan jumlah oksigen sama, otot yang terlatih akan lebih efektif kerjanya (Giriwijoyo,S., Ali, M. 2005: 57).

Pada orang yang dilatih selam beberapa bulan terjadi perbaikan pengaturan pernapasan. Perbaikan ini terjadi karena menurunnya kadar asam laktat darah, yang seimbang dengan pengurangan penggunaan oksigen oleh jaringan tubuh. Latihan fisik akan mempengaruhi organ sedemikian rupa sehingga kerja organ lebih efisien dan kapasitas kerja maksimum yang dicapai lebih besar. Faktor yang paling penting dalam perbaikan kemampuan pernapasan untuk mencapai tingkat optimal adalah kesanggupan untuk meningkatkan capillary bed yang aktif, sehingga jumlah darah yang mengalir di paru lebih banyak dan darah yang berikatan dengan oksigen per unti waktu juga akan meningkat. Peningkatan ini digunakan untuk memenuhi kebutuhan jaringan terhadap oksigen (Giriwijoyo,S., Ali, M. 2005: 57). Penurunan fungsi paru orang yang tidak berolahraga atau usia tua terutama disebabkan oleh hilangnya elastisitas paru-paru dan otot dinding dada. Hal ini menyebabkan penurunan nilai kapasitas vital dan nila forced expiratory volume, serta meningkatkan volume residual paru (Giriwijoyo,S., Ali, M. 2005: 57).

Latihan ketahanan berpengaruh terhadap kualitas sistem kardiovaskuler, pernafasan, dan sistem peredaran darah. Ada beberapa keuntungan bagi olahragawan yang memiliki ketahanan yang baik, antara lain: (1) Menambah kemampuan untuk melakukan kerja secara terus menerus dengan intensitas tinggi dalam jangka waktu lama, (2) menambah kemampuan untuk memperpendek waktu pemulihan, dan (3) menambah kemampuan untuk menerima 


\section{MEDIKORA Vol. VIII, No 2 April 2012}

beban latihan yang lebih berat dan bervariasi (Russel Pate R. Cleaneghan Mc Bruce. Rotella, 1993: 64).

\section{TEKANAN DARAH}

Tekanan darah merujuk kepada tekanan yang dialami darah pada pembuluh arteri ketika darah dipompa oleh jantung ke seluruh anggota tubuh manusia. Tekanan darah dibuat dengan mengambil dua ukuran dan biasanya diukur seperti berikut: 120 /80 mmHg. Nilai atas (120) menunjukkan tekanan pembuluh arteri akibat denyutan jantung, dan disebut tekanan sistole. Nilai bawah (80) menunjukkan tekanan saat jantung beristirahat di antara pemompaan, dan disebut tekanan diastolik. Menurut Dede Kusmana (2002: 86) tekanan darah dalam kehidupan seseorang bervariasi secara alami. Faktor-faktor yang mempertahankan tekanan darah yaitu antara lain: kekuatan memompa jantung, banyaknya darah yang beredar, kekentalan darah, elastisitas dinding pembuluh darah, dan tahanan tepi. Sedangkan faktor yang dapat mempengaruhi tekanan darah seseorang yaitu antara lain: umur, jenis kelamin, emosi, aktivitas kerja, sikap tubuh (tidur, duduk), waktu (pagi, siang, malam)

Tekanan darah merupakan tenaga yang digunakan darah yang dipompakan dari jantung untuk melawan tahanan pembuluh darah, atau sejumlah tenaga yang dibutuhkan untuk mengedarkan darah ke seluruh tubuh. Sepanjang hari, tekanan darah akan berubah-ubah tergantung dari aktivitas tubuh. Tekanan darah bergantung kepada jantung sebagai pompa dan resistensi pembuluh darah perifer. Jumlah darah yang dipompa oleh jantung setiap menit dinamakan cardiac output (curah jantung). Curah jantung dipengaruhi oleh kecepatan denyut jantung dan volume darah yang dipompakan pada setiap denyutan. Pada umumnya tekanan darah tidak stabil sepanjang hari, tetapi menunjukkan fluktuasi yang dipengaruhi oleh aktivitas, emosi dan sebagainya, terutama tekanan sistolik. Sedangkan tekanan diastolik relatif stabil, oleh karena itu tekanan darah yang normal harus ditentukan tidak pada suatu saat saja, tetapi berulang-ulang.

Tekanan darah pada setiap orang bisa mengalami tekanan darah yang tinggi dan juga bisa mengalami tekanan darah yang rendah. Tekanan darah yang naik di atas yang normal atau tekanan darah yang tinggi disebut hipertensi. Sedangkan tekanan darah yang di bawah normal atau tekanan darah yang rendah disebut hipotensi. Hipertensi dapat disebabkan oleh beberapa faktor antara lain faktor keturunan, konsumsi garam dapur melebihi $15 \mathrm{~g} / \mathrm{hari}$, berat badan berlebihan, kurang beraktivitas fisik, serta faktor mental (stress), serta penggunaan obat tertentu yang dapat meningkatkan tekanan darah (Syaifuddin, 2001: 48 ).

\section{Adaptasi Sistem Kardiovasculer}




\section{MEDIKORA Vol. VIII, No 2 April 2012}

Denyut jantung yang lebih rendah pada seorang olahragawan karena meningkatnya pengaruh saraf vagus dan berkurangnya pengaruh simpatis. Jadi latihan, dapat membantu jantung menjadi lebih efisien dan dapat mengedarkan lebih banyak darah dengan jumlah denyut yang lebih rendah. Salah satu fungsi utama jantung adalah sebagai alat transportasi pengangkutan gas oksigen dan karbondioksida. Dalam fungsinya sebagai pembawa gas, fungsi ini tidak lepas dari fungsi paru-paru, sehingga kedua alat tersebut sulit sekali dipisahkan sebagai kesatuan fungsi yang lebih sering disebut sebagai istilah kardiorespirasi. Akibatnya ialah pada waktu aktivitas tidak mungkin salah satu system cardiorespirasi meningkat maka yang lainnya akan meningkat pula. Di dalam suatu aktivitas fisik kebutuhan otot akan oksigen meningkat dari keadaan normal, hal ini menyebabkan tubuh akan mengoptimalkan sistem kardiorespirasi untuk memasok kebutuhan otot akan oksigen. Hal ini membuat kerja jantung akan naik sesuai dengan tingkat berat aktivitas latihan tersebut. Parameter untuk mengukur mengetahui berat atau tidaknya suatu latihan seseorang adalah bisa dengan melihat sistem kardiorespirasi (Kiyonaga dkk, yang dikutip dari Kurniawan, C., 2006125-131:

Denyut jantung waktu istirahat pada olahragawan yang terlatih menjadi lebih lambat dibandingkan dengan yang tidak terlatih. Meningkatnya efisiensi jantung, mengakibatkan aliran darah yang mencapai otot menjadi lebih banyak, dengan adanya persediaan makanan dan $\mathrm{O}_{2}$ yang memadai, memungkinkan seseorang mencapai hasil yang lebih tinggi. Sebagai tambahan dari perubahan-perubaha fungsional tersebut di atas, latihan juga menimbulkan perubahan strukural dari jantung. Dengan latihan seseorang mampu menghentikan pekerjaannya dengan kadar asam laktat yang lebih tinggi di dalam darah, yang berarti dia lebih mampu daripada sebelumnya. Bila darah terlalu banyak mengandung asam laktat atlet menjadi kehabisan tenaga (exhaustion). Berdasarkan hal ini banyak orang berfikir dengan memberikan buffer atau cukup alkali akan dapat memperbaiki kapasitas latihan (Sherwood Lauralle, 1996: 109). Penjelaskan tentang perubahan kardiovaskuler selama melakukan olahraga dapat dilihat pada tabel 1 sebagai berikut:

Tabel 1. Perubahan Kardiovaskuler Selama Melakukan Olahraga

\begin{tabular}{|l|l|l|}
\hline Variabel kardiovaskuler & Perubahan & Keterangan \\
\hline Kecepatan denyut jantung & Meningkat & $\begin{array}{l}\text { Terjadi akibat peningkatan aktivitas simpatis dan } \\
\text { penurunan aktivitas parasimpatis pada nodus SA }\end{array}$ \\
\hline Aliran balik vena & Meningkat & $\begin{array}{l}\text { Terjadi akibat vasokontriksi vena yang diinduksi oleh } \\
\text { syaraf simpatis serta peningkatan aktivitas pompa otot }\end{array}$ \\
\hline
\end{tabular}




\begin{tabular}{|c|c|c|}
\hline & & rangka dan pompa respirasi \\
\hline Volume sekuncup & Meningkat & $\begin{array}{l}\text { Terjadi akibat peningkatan aliran balik vena melalui } \\
\text { mekanisme Frank-Starling (kecuali apabila waktu } \\
\text { pengisian berkurang secara bermakna akibat tingginya } \\
\text { kecepatan denyut jantung) dan akibat peningkatan } \\
\text { kontraktilitas miokardium yang distimulasi oleh syaraf } \\
\text { simpatis }\end{array}$ \\
\hline Curah jantung & Meningkat & $\begin{array}{l}\text { Terjadi akibat peningkatan kecepatan denyut jantung dan } \\
\text { volume sekuncup }\end{array}$ \\
\hline $\begin{array}{llll}\text { Aliran } & \text { darah } & \text { ke } & \text { otot } \\
\text { rangka } & \text { aktif dan } & \text { otot } \\
\text { jantung } & & & \end{array}$ & Meningkat & $\begin{array}{l}\text { Terjadi akibat vasodilatasi ateriol yang dikontrol secara } \\
\text { lokal, yang diperkuat oleh efek vasodilatasi epineprin dan } \\
\text { kalahnya efek vasokontriksi simpatis yang lebih lemah }\end{array}$ \\
\hline Aliran darah ke otak & $\begin{array}{l}\text { Tidak } \\
\text { berubah }\end{array}$ & $\begin{array}{l}\text { Terjadi karena stimulasi simpatis tidak berefek pada } \\
\text { arteriol otak, mekanisme kontrol lokal mempertahankan } \\
\text { aliran darah ke otak konstan, apaun keadaannya. }\end{array}$ \\
\hline Aliran darah ke kulit & Meningkat & $\begin{array}{l}\text { Terjadi karena pusat kontrol hipotalamus menginduksi } \\
\text { arteriol kulit, peningkatan aliran darah kulit membawa } \\
\text { panas yang dihasilkan oleh otot yang berolahraga } \\
\text { kepermukaan tubuh, sehingga panas dapat disalurkan ke } \\
\text { lingkungan luar. }\end{array}$ \\
\hline $\begin{array}{l}\text { Aliran darah ke saluran } \\
\text { pencernaan, ginjal dan } \\
\text { organ lain }\end{array}$ & Menurun & $\begin{array}{l}\text { Terjadi akibat vasokontriksi arteriol yang diinduksi oleh } \\
\text { syaraf simpatis secara umum. }\end{array}$ \\
\hline Resistensi perifer total & Menurun & $\begin{array}{l}\text { Terjadi karena resistensi di otot-otot rangka, jantung, dan } \\
\text { kulit menurun dengan tingkat lebih besar daripada } \\
\text { peningkatan resistensi di organ-organ lain }\end{array}$ \\
\hline $\begin{array}{l}\text { Tekanan darah arteri rata- } \\
\text { rata }\end{array}$ & $\begin{array}{l}\text { Meningkat } \\
\text { (sedang) }\end{array}$ & $\begin{array}{l}\text { Terjadi curah jantung meningkat lebih besar daripada } \\
\text { penurunan resistensi perifer total }\end{array}$ \\
\hline
\end{tabular}

\section{METODE PENELITIAN}

Jenis Penelitian ini adalah " Quasi Experiment" dengan desain penelitian “One Group Pretest-Posttest design " yang terdiri dari 1 kelompok perlakuan, di mana perlakuan yang 


\section{MEDIKORA Vol. VIII, No 2 April 2012}

diberikan adalah latihan tenis secara terprogram dan terukur selama 12 minggu. Populasi dalam penelitian ini adalah dari Atlet Pelatda Sleman cabang tenis lapangan. Sampel penelitian diambil dari populasi terjangkau yang berusia antara 12-20 tahun, memiliki nilai Indeks Massa Tubuh antara 18,5-24,9 kg/m², bukan atlet yang biasa melakukan latihan olahraga berat, tidak mengkonsumsi alkohol, dan tidak mempunyai riwayat penyakit kardiovaskuler (hipertensi, penyakit jantung).

Subjek penelitian adalah seluruh populasi dari Atlet Pelatda Sleman cabang tenis lapangan. Pengumpulan data dilakukan dengan mengukur dan mencatat nilai tekanan darah sebelum dan sesudah melakukan latihan olahraga dengan beban tertentu dalam waktu tertentu. Pengumpulan data nilai tekanan darah dilakukan oleh tim peneliti, mengambil tempat di Lapangan Tenis Fakultas Ilmu Keolahragaan Universitas Negeri Yogyakarta.

Penelitian ini dilaksanakan pada bulan April-Juli tahun 2011, di kampus Fakultas Ilmu Keolahrgaan Universitas negeri Yogyakarta. Data yang dikumpulkan adalah data primer dari Atlet Pelatda Sleman cabang tenis lapangan, yang didapat dari pengukuran tekanan darah istirahat dan berupa kuesioner yang berisi pertanyaan meliputi nama, umur, tinggi badan, berat badan, kebiasaan berolahraga, konsumsi alkohol dan riwayat penyakit kardiovaskuler.

\section{HASIL PENELITIAN DAN PEMBAHASAN}

Data pada penelitian ini dambil dengan instrumen test kebugaran dan pengukuran tekanan darah. Deskripsi data, secara ringkas disajikan pada uraian berikut ini.

\section{a. Kebugaran}

Kebugaran pada penelitian ini adalah daya tahan kardiorespirasi pada atlet Pelatda Sleman cabang tenis lapangan dan distribusinya disajikan pada tabel berikut ini.

Tabel 2. Tingkat Kebugaran pada Atlet Pelatda Sleman Cabang Tenis Lapangan $(n=10)$

\begin{tabular}{|l|l|l|l|l|l|}
\hline \multirow{2}{*}{ No. } & \multirow{2}{*}{ Kategori Kebugaran } & \multicolumn{4}{l|}{ Kebugaran } \\
\cline { 3 - 6 } & & \multicolumn{2}{l|}{ Awal } & \multicolumn{2}{l|}{ Akhir } \\
\cline { 3 - 6 } & & $\mathrm{f}$ & $\%$ & $\mathrm{f}$ & $\%$ \\
\hline 1. & Sangat Baik & 1 & 10,0 & 2 & 20,0 \\
\hline 2. & Di Atas Rata-rata & 4 & 40,0 & 6 & 60,0 \\
\hline 3. & Rata-rata & 3 & 30,0 & 1 & 10,0 \\
\hline 4. & Di Bawah Rata-rata & 2 & 20,0 & 1 & 10,0 \\
\hline 5. & Buruk & 0 & 0,0 & 0 & 0,0 \\
\hline
\end{tabular}




\begin{tabular}{|l|l|l|l|l|}
\hline Total & 10 & 100,0 & 10 & 100,0 \\
\hline
\end{tabular}

Berdasarkan analisis deskriptif, diperoleh nilai mean untuk tingkat kebugaran awal 2364,00; median 2415,00; mode 1950; dan standart deviasi 273,707. Adapun nilai mean untuk tingkat kebugaran akhir 2467,00; median 2480,00; mode 2520; dan standart deviasi 230,654 .

\section{b. Tekanan Darah}

Tekanan darah dilakukan dengan pengukuran tekanan darah pada atlet Pelatda Sleman cabang tenis lapangan yang terdiri dari tekanan darah sistole dan diastole. Dstribusinya tekanan darah berdasarkan kategori, disajikan pada tabel berikut ini.

Tabel 3. Tekanan Darah pada Atlet Pelatda Sleman Cabang Tenis Lapangan $(\mathrm{n}=\mathbf{1 0})$

\begin{tabular}{|l|l|c|c|c|c|}
\hline \multirow{2}{*}{ No. } & \multirow{2}{*}{ Kategori Tekanan Darah } & \multicolumn{4}{|c|}{ Tekanan Darah } \\
\cline { 3 - 6 } & & \multicolumn{2}{|c|}{ Awal } & \multicolumn{2}{|c|}{ Akhir } \\
\cline { 3 - 6 } & & f & \% & f & $\%$ \\
\hline 1. & Optimal & 2 & 20,0 & 7 & 70,0 \\
\hline 2. & Normal & 4 & 40,0 & 2 & 2,0 \\
\hline 3. & Borderline & 3 & 30,0 & 1 & 1,0 \\
\hline 4. & Hipertensi & 1 & 10,0 & 0 & 0,0 \\
\hline 5. & Stadium 1 & 0 & 0,0 & 0 & 0,0 \\
\hline 6. & Stadium 2 & 0 & 0,0 & 0 & 0,0 \\
\hline 7. & Stadium 3 & 0 & 0,0 & 0 & 0,0 \\
\hline & Total & 10 & 100,0 & 10 & 100,0 \\
\hline
\end{tabular}

Berdasarkan analisis deskriptif, diperoleh nilai mean untuk tekanan darah sistole awal 126,60; median 127,00; mode 127; dan standart deviasi 10,741; adapun nilai mean untuk tekanan darah diastole awal 83,90; median 82,50; mode 82; dan standart deviasi 7,047. Dari analisis tersebut juga dihasilkan nilai mean untuk tekanan darah sistole akhir 119,90; median 121,00; mode 120; dan standart deviasi 6,887; adapun nilai mean untuk tekanan darah diastole akhir 79,50; median 79,50; mode 75; dan standart deviasi 3,866.

\section{Pengujian Hipotesis}

Hipotesis pada penelitian ini adalah: "setelah mengikuti latihan tenis secara teratur selama 12 minggu, tekanan darah akan mengalami penurunan dan daya tahan kardio-respirasi akan mengalami peningkatan”. Guna pengujian hipotesis ini, data dianalisis dengan teknik analisis statistik non parametrik, yaitu dengan Wilcoxon Signed Ranks Test. Sebelumnya data diuji normalitasnya dengan Kolmogorov-Smirnov dan Shapiro-Wilk, berikut hasil analisisnya: 
Tabel 4. Hasil Analisis Uji Normalitas Sebaran Data

Tests of Normality

\begin{tabular}{|l|r|r|r|r|r|r|}
\hline & \multicolumn{3}{|c|}{ Kolmogorov-Smirnov $^{2}$} & \multicolumn{3}{|c|}{ Shapiro-Wilk } \\
\cline { 2 - 7 } & Statistic & \multicolumn{1}{|c|}{$\mathrm{df}$} & \multicolumn{1}{c|}{ Sig. } & \multicolumn{1}{c|}{ Statistic } & \multicolumn{1}{c|}{ df } & \multicolumn{1}{c|}{ Sig. } \\
\hline Kebugaran (Awal) & .152 & 10 & $.200^{*}$ & .970 & 10 & .891 \\
TD Sistole (Awal) & .134 & 10 & $.200^{\star}$ & .959 & 10 & .777 \\
TD Diastole (Awal) & .151 & 10 & $.200^{\star}$ & .938 & 10 & .531 \\
Kebugaran (Akhir) & .109 & 10 & $.200^{\star}$ & .985 & 10 & .987 \\
TD Sistole (Akhir) & .206 & 10 & $.200^{\star}$ & .950 & 10 & .670 \\
TD Diastole (Akhir) & .149 & 10 & $.200^{*}$ & .933 & 10 & .479 \\
\hline
\end{tabular}

${ }^{*}$. This is a lower bound of the true significance.

a. Lilliefors Significance Correction

Berdasarkan hasil uji normalitas seperti tersaji pada tabel tersebut di atas, dinyatakan bahwa semua data pada penelitian ini, yaitu: (1) kebugaran awal; (2) tekanan darah sistole awal; (3) tekanan darah diastole awal; : (4) kebugaran akhir; (5) tekanan darah sistole akhir; dan (6) tekanan darah diastole akhir berdistribusi normal. Hal ini ditunjukkan dengan nilai Kolmogorov-Smirnof dan Shapiro-Wilk memiliki pvalue (sig.) lebih besar dari 5\% ( $>00,05)$. Adapun hasil analisis uji beda dengan Wilcoxon Signed Ranks Test, secara ringkas disajikan pada tabel berikut ini.

Tabel 5. Hasil Analisis Wilcoxon Signed Ranks Test Test Statistics c c

\begin{tabular}{|l|c|c|c|}
\hline & $\begin{array}{c}\text { Kebugaran } \\
\text { (Akhir) }- \\
\text { Kebugaran } \\
\text { (Awal) }\end{array}$ & $\begin{array}{c}\text { TD Diastole } \\
\text { TD Sistole } \\
\text { (Akhir) - TD } \\
\text { Sistole (Awal) }\end{array}$ & $\begin{array}{c}\text { (Akhir) - TD } \\
\text { Diastole } \\
\text { (Awal) }\end{array}$ \\
\hline Z & -2.812 a & -2.601 o & -2.296 D \\
Asymp. Sig. (2-tailed) & .005 & .009 & .022 \\
\hline
\end{tabular}

a. Based on negative ranks.

b. Based on positive ranks.

c. Wilcoxon Signed Ranks Test

\section{PEMBAHASAN}

\section{a. Pengaruh Latihan Tenis Terhadap Daya Tahan Kardiorespirasi (Kebugaran)}

Latihan olahraga dapat mengakibatkan efisiensi otot pernafasan meningkat, yang dapat dilihat dengan ventilasi paru/menit; frekuensinya menurun, sedang dalamnya bertambah. Orang terlatih, frekuensi dapat sampai $8 \mathrm{kali} /$ menit sewaktu istirahat, tetapi dilakukan lebih dalam. Sedang volume semenit untuk pekerjaan tertentu bisa hanya 25\% daripada sebelumnya. Volume paru-paru tidak dipengaruhi oleh latihan. Ini berarti bahwa penggunaan kapasitas vital untuk pengukuran kesegaran jasmani tidak memenuhi syarat. 


\section{MEDIKORA Vol. VIII, No 2 April 2012}

Pembesaran kapasitas vital yang didapat pada atlet yang terlatih, lebih berhubungan dengan proses pertumbuhannya daripada rangsangan latihannya. Hasil uji beda dengan Wilcoxon Signed Ranks Test pada data kebugaran (awal $><$ akhir) diperoleh nilai $\mathrm{Z}=$ 2,812 dengan p-value (sig) $=0,005$ dengan catatan: based on negative ranks. Ternyata $\mathrm{p}<0,05$ hal ini menunjukkan bahwa ada perbedaan yang signifikan antara tingkat kebugaran sebelum dengan sesudah mengikuti latihan tenis secara teratur selama 12 minggu. Perbedaan itu berupa peningkatan, yang ditunjukkan dengan catatan bahwa based on negative rank.

Pengaruh latihan terprogram terhadap pembuluh darah adalah: pembuluh darah akan melebar (vasodilatasi), panas tubuh akan melebarkan pembuluh darah, dan elasitisitas dinding pembuluh darah yang baik (khususnya pada olahraga yang bersifat aerob) terjadi pada tubuh. Kecepatan denyut jantung adalah salah satu faktor yang paling mudah dipantau yang memperlihatkan baik respon segera terhadap olahraga maupun adaptasi jangka panjang terhadap program olahraga tertentu. Sewaktu seseorang melakukan gerak badan (berolahraga) sel-sel otot yang aktif menggunakan lebih banyak oksigen untuk menunjang peningkatan kebutuhan energi yang digunakan pada waktu berolahraga

Hal ini juga dibuktikan dengan peningkatan pada skor daya tahan kardiorespirasi (kebugaran), yakni rata-rata kebugaran sebelum latihan sebesar 2364,00; sedangkan ratarata kebugaran setelah mengikuti latihan secara teratur selama 12 minggu meningkat menjadi 2467,00. Dengan demikian hipotesis pada penelitian ini terbukti kebenarannya, yaitu ada peningkatan yang signifikan $(\mathrm{p}<0,05)$ daya tahan kardiorespirasi pada atlet Pelatda Sleman cabang tenis lapangan setelah mengikuti latihan tenis secara teratur selama 12 minggu.

\section{b. Pengaruh Latihan Tenis Terhadap Penuruan Tekanan Darah}

Latihan otot menyebabkan berkembangnya mekanisme penghambatan di otak atau di hipotalamus, yang menyebabkan aktivitas adrenergik rendah pada waktu istirahat. Hal ini menunjukkan bahwa denyut jantung yang lebih rendah pada seorang olahragawan karena meningkatnya pengaruh saraf vagus dan berkurangnya pengaruh simpatis. Jadi dengan latihan, jantung menjadi lebih efisien dan dapat mengedarkan lebih banyak darah dengan jumlah denyut yang lebih rendah. Hasil uji beda dengan Wilcoxon Signed Ranks Test pada data tekanan darah sistole (awal $><$ akhir) diperoleh nilai $\mathrm{Z}=-2,601$ dengan $p$ value $(\mathrm{sig})=0,009$ dengan catatan: based on positive ranks. Ternyata $\mathrm{p}<0,05$; hal ini 


\section{MEDIKORA Vol. VIII, No 2 April 2012}

menunjukkan bahwa ada perbedaan yang signifikan antara tekanan darah sistole sebelum dengan sesudah mengikuti latihan tenis secara teratur selama 12 minggu. Perbedaan itu berupa penurunan, yang ditunjukkan dengan catatan bahwa based on positive rank.

Denyut jantung waktu istirahat pada olahragawan yang terlatih menjadi lebih lambat dibanding yang tidak terlatih. Meningkatnya efisiensi jantung, mengakibatkan aliran darah yang mencapai otot menjadi lebih banyak, dengan adanya persediaan makanan dan $\mathrm{O}_{2}$ yang memadai, memungkinkan seseorang mencapai hasil yang lebih tinggi. Sebagai tambahan dari perubahan-perubahan fungsional tersebut di atas, latihan juga menimbulkan perubahan strukural dari jantung. Hasil uji beda dengan Wilcoxon Signed Ranks Test pada data tekanan darah diastole (awal $><$ akhir) diperoleh nilai $\mathrm{Z}=$ 2,2961 dengan $p$-value (sig) $=0,022$ dengan catatan: based on positive ranks. Ternyata $\mathrm{p}<0,05$; hal ini menunjukkan bahwa ada perbedaan yang signifikan antara tekanan darah diastole sebelum dengan sesudah mengikuti latihan tenis secara teratur selama 12 minggu. Perbedaan itu berupa penurunan, yang ditunjukkan dengan catatan bahwa based on positive rank.

Hal ini juga dibuktikan dengan penurunan tekanan darah sistole, yakni rerata tekanan darah sistole sebelum latihan sebesar 126,60; sedangkan rata-rata tekanan darah sistole setelah mengikuti latihan secara teratur selama 12 minggu meningkat menjadi 119,90. Penurunan tekanan darah diastole, sebelum latihan sebesar 83,90; sedangkan ratarata tekanan darah diastole setelah mengikuti latihan secara teratur selama 12 minggu meningkat menjadi 79,50.

Bertambah banyaknya pembuluh-pembuluh darah kapiler otot akan memperbaiki asupan darah keotot. Dengan demikian hipotesis pada penelitian ini terbukti kebenarannya, yaitu ada penurunan yang signifikan $(p<0,05)$ tekanan darah pada atle Pelatda Sleman cabang tenis lapangan setelah mengikuti latihan tenis secara teratur selama 12 minggu.

\section{KESIMPULAN}

Pada saat orang berolahraga jantung dan sistem peredaran darah harus bekerja lebih banyak dengan kardiorespirasi yang semakin cepat dan tekanan darah akan meningkat. Perubahan ini terjadi ada yang bersifat sementara dan ada yang bersifat tetap, dimulai dengan perubahan fisiologis dan dalam waktu yang relatif lama akan terjadi perubahan morfologis yang lebih konsisten. Olahraga Diantara banyak manfaat olahraga tenis yang lain, salah satunya adalah bahwa olahraga tenis dapat meningkatkan daya tahan kardiorespirasi dan 


\section{MEDIKORA Vol. VIII, No 2 April 2012}

tekanan darah. Respon fisiologis terhadap olahraga adalah meningkatnya curah jantung yang akan disertai meningkatnya distribusi oksigen ke bagian tubuh yang membutuhkan.

Respon fisiologis terhadap olahraga adalah meningkatnya curah jantung yang akan disertai meningkatnya distribusi oksigen ke bagian tubuh yang membutuhkan, sedangkan pada bagian-bagian yang kurang memerlukan oksigenakan terjadi vasokonstriksi, misal traktus digestivus. Meningkatnya curah jantung pasti akan berpengaruh terhadap tekanan darah. Kesimpulan yang dapat diambil, berdasarkan hasil penelitian dan pembahasan adalah sebagai berikut: (1) Ada peningkatan dayatahan kardiorespirasi yang signifikan $(p<0,05)$ pada atlet Pelatda Sleman cabang tenis lapangan setelah mengikuti latihan tenis secara teratur selama 12 minggu. (2) Ada penurunan tekanan darah yang signifikan $(\mathrm{p}<0,05)$ pada atlet Pelatda Sleman cabang tenis lapangan setelah mengikuti latihan tenis secara teratur selama 12 minggu.

\section{DAFTAR PUSTAKA}

Bompa, Tudor O (1994). Theory and Methodology of Training. The Key to Athletic Performance, $3^{\text {rd }}$ Edition. Dubuque. Lowa: Kendal/Hunt Publishing Company.

Cerika Rismayanthi (2009). Pengaruh Latihan Senam Jantung Indodenesia Terhadap Penurunan Tekanan Darah pada Penderita Hipertensi. Thesis. Pps IK UNY. Yogyakarta.

Dede Kusmana. (2002). Olahraga bagi Kesehatan Jantung, Jakarta: Fakultas Kedokteran Universitas Indonesia.

Giam, C.K., 1993, Ilmu Kedokteran Olahraga. Salma, 1994. (citase). Bina RupaAksara, Jakarta

Giriwijoyo,S., Ali, M. 2005, Ilmu Faal Olahraga: Fungsi Tubuh Manusia pada Olahraga untuk Kesehatan dan Prestasi. Fak. Pendidikan olahraga \&kesehatan UPI, BandungGledhill, N., 2002.

Kiyonaga,A., Arakawa,K., Tanaka,H., Shindo,M., Blood Pressure and Hormonal Responses to Aerobic Exercise, Hypertension by AHA 1985;7;125-131Kurniawan, C., 2006. Sinopsis Fisiologi. PiDi Publisher, Yogyakarta.

Sherwood Lauralle, 1996. Fisiologi Manusia dari Sel ke Sistem, edisi 2, Penerbit Buku Kedokteran EGC, cetakan 1:2001

Sukadiyanto.(2002). Teori dan Metodologi Melatih Fisik Petenis. Yogyakarta: Fakultas Ilmu Keolahragaan UNY.

Syaifuddin, 2001. Fungsi Sistem Tubuh Manusia. Widya Medika, Jakarta. 
Russel Pate R. Cleaneghan Mc Bruce. Rotella. (1993). Scientific Foundation of Coaching. (Alih Bahasa oleh Kasiyo Dwijowinoto, dasar-Dasar Kepelatihan Ilmiah) semarang: IKIP Semarang Press. 